\title{
Human reproduction: current status
}

\author{
Carlos Roberto Izzo ${ }^{1 *}$, Pedro Augusto Araújo Monteleone² ${ }^{2}$ Paulo C. Serafini ${ }^{3}$ \\ ${ }^{1}$ Assistant, PhD, Division of Gynecology, Department of Obstetrics and Gynecology, Faculdade de Medicina, Universidade de São Paulo (FMUSP), São Paulo, SP, Brazil \\ ${ }^{2}$ Administrative Coordinator of the Human Reproduction Center, Department of Obstetrics and Gynecology, FMUSP, São Paulo, SP, Brazil \\ ${ }^{3}$ Associate Professor, Habilitation (BR: Livre Docência), Department of Obstetrics and Gynecology, FMUSP, São Paulo, SP, Brazil
}

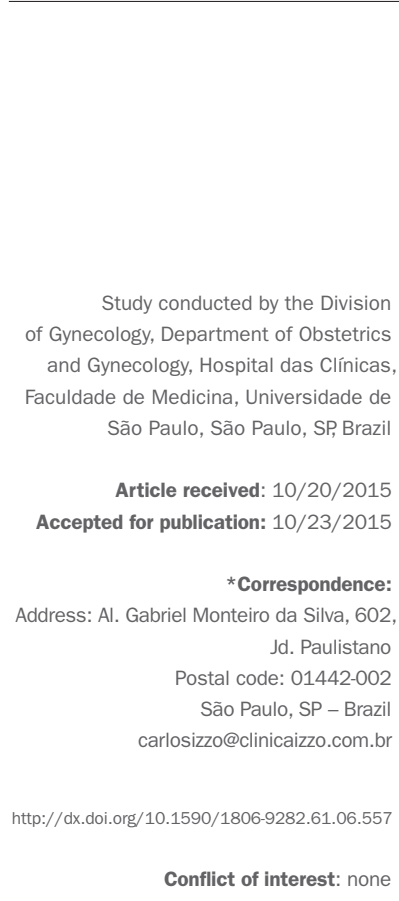

\section{SUMMARY}

The concern about the maintenance of the human species has existed since the earliest civilizations. Progress in the diagnosis and treatment of infertility has led to the development of assisted reproductive techniques (ART) which, along with the evolution of genetics and molecular biology studies, have contributed in a concrete way to the management of infertile couples. Classic in vitro fertilization was initially developed 35 years ago for the treatment of women with tubal blockage, however, it remains inaccessible to a significant proportion of infertile couples around the world. This can be explained by the lack of specialized clinics in some countries and by the high cost of the procedures. Efforts have been employed to increase the number of treatment cycles for assisted reproduction, as for example, the creation of low-cost programs. Even today, infertility remains a problem of global proportions, affecting millions of couples. The estimate of the incidence of infertility is uncertain, mainly because of the criteria used for its definition. This article aims to review the most important aspects, succinctly, regarding the incidence, etiology, and treatment options available to infertile couples.

Keywords: infertility, techniques of assisted reproduction (ART), in vitro fertilization.

\section{INTRODUCTION}

Reproduction and maintenance of the human species are concerns since the most ancient civilizations. Egyptians, Greeks and Babylonians have linked the occurrence of intercourse with the birth of a child and were concerned to discuss the etiology and possible treatments for couples who had no children. In ancient Rome, it was believed that infertility was linked to sex at the wrong time during the menstrual cycle and the best time recommended for conception was that soon after the end of menstrual bleeding.

As of the sixteenth century, scientific observations have resulted in outstanding contributions to the development of medicine, especially studies in anatomy and physiology. The role of endocrinology in infertility began to unravel in the early nineteenth century. The hypothalamic-hypophyseal-ovarian axis was described in the early twentieth century.

The development of tubal surgery and endoscopy, over the past century, has allowed progress in the assessment and treatment of tubo-peritoneal diseases. All this improvement in the diagnosis and treatment of infertility led to in vitro fertilization and assisted reproduction techniques which, together with genetic and molecular biology, have become a real solution promise for infertile couples. ${ }^{1}$
Techniques of assisted reproduction (ART), such as classic in vitro fertilization, were initially developed for the treatment of women with tubal obstruction aged over 35 years, and remain inaccessible to a significant proportion of infertile couples worldwide. The lack of specialized clinics in some countries and the high cost of procedures, led to efforts to create low-cost treatment programs, which often lead infertile couples to undergo treatment cycles in services outside their country of origin.

Infertility, or the lack of conception, remains a problem of global proportions. This is true in the second decade of the new millennium. Millions of people around the world are diagnosed with infertility. It is difficult to estimate the total infertile population in the world, due to the heterogeneity of the criteria used to define infertility, to important differences in the estimation of infertility based on large scale population studies versus epidemiological studies, and the complete absence of the prevalence of male infertility. ${ }^{2,3}$ Three surveys on the overall prevalence of infertility published in the new millennium (2004, 2007 and 2012) have very different results, between 48.5 million and 186 million. ${ }^{4-6}$ Secondary infertility or lack of conception after a previous pregnancy is the most common form of female infertility around the world. 


\section{Definition}

Marital infertility is defined as a couple's inability to conceive after a year of active and regular sex life, without the use of effective contraception. Primary infertility refers to women who have never been pregnant, while secondary refers to those who have been pregnant at least once before fitting the criteria that define infertility. ${ }^{7}$

\section{EpIDEMIOLOGY}

Infertility remains a highly prevalent condition worldwide. It is estimated that it may affect between 8 and $12 \%$ of couples at reproductive age, ${ }^{8,9}$ with a probable global incidence average of $9 \% .{ }^{4}$ In some regions of the world the incidence of infertility can achieve rates of $30 \%$ in specific populations, ${ }^{8-10}$ especially in southern and central Asia, East and North Africa and Eastern Europe. ${ }^{6}$

Approximately 10 to $15 \%$ of couples in big cities of industrialized countries are struggling to achieve a pregnancy, contributing to a significant portion of the consultations with gynecologists. A young, healthy couple has about a $20 \%$ chance of getting pregnant per menstrual cycle and approximately $90 \%$ in a year of regular attempts. ${ }^{11}$ In 30 to $40 \%$ of infertile couples, the cause of infertility is related to the woman; other $40 \%$ is due to the male factor, and 20 to $30 \%$ of the remaining cases are related to the combination of the two factors, which calls for the diagnosis and comprehensive treatment of the couple.

Some factors affect the fertility of a normal couple, influencing the chance of getting pregnant naturally: frequency of sexual intercourse, the woman's age, smoking, exercise, body weight of women, use of drugs or medications, pelvic infection, previous abdominal surgery, and psychological factors.

Couples who have active and regular sex are more likely to get pregnant than those who have sporadic sex because it is more likely that the sexual intercourse will coincide with the fertile period of the woman.

The reproductive capacity of women is inversely proportional to their chronological age, since the quality of oocytes diminishes throughout the reproductive life and this decrease becomes more pronounced after the age of 35 years. The more advanced the age of the woman, the greater the difficulty of a natural pregnancy, the greater the rate of spontaneous abortion, the higher the incidence of chromosomal abnormalities in the embryo, and the lower the success rate of human reproduction treatment. ${ }^{12}$

Some social factors can contribute to infertility related to the woman's age. Currently, women invest in their education and careers, have access to effective contraception and delay marriage and childbearing to older age.

The length of the couple's infertility is a significant prognostic factor. The longer the duration of infertility, the more complex a treatment approach will be.

\section{Etiology}

The most common causes of female infertility are anatomical abnormalities (congenital or acquired), ovulatory disorders and pelvic endometriosis. Many infertility factors are easily treated if properly diagnosed.

\section{TREATMENT}

Treatment of the infertile couple should be as differentiated and individualized as possible. Couples being treated should do so always taking into account their diagnosis, starting with simpler and less expensive therapeutic alternatives. If pregnancy does not occur, the couple should follow a treatment schedule that will become increasingly complex and technologica. ${ }^{13-15}$

In order of increasing complexity, therapy begins with timed intercourse, either using ovulation stimulatory drugs or not. Monitoring follicular growth with transvaginal ultrasound, the time of ovulation is determined and, thus, it is possible to guide the sexual activity at the appropriate time for conception.

Then, there is intrauterine insemination, which can count on controlled ovarian stimulation or not. At the time of ovulation, a catheter is inserted through the cervix into the endometrial cavity to insert the partner's semen after in vitro processing aimed at improving seminal quality.

In case of failure of low-complexity treatments, in vitro fertilization is indicated. In ovarian stimulation using exogenous gonadotropins, greater numbers of oocytes are obtained. In the laboratory, micro-manipulation of gametes is performed to approximate egg and sperm to form the embryo, which is transferred to the patient's womb.

This sequence of treatment is not mandatory for all patients. Several factors should be considered for therapeutic indication and each case must be unique.

\section{Resumo}

Reprodução humana: estado atual

A preocupação com a procriação e a manutenção da espécie humana existe desde as civilizações mais antigas. $\mathrm{O}$ progresso no diagnóstico e no tratamento da infertilidade teve 
como consequência o desenvolvimento de técnicas de reprodução assistida (TRA) que, conjuntamente com a evolução dos estudos em genética e biologia molecular, têm contribuído de maneira real no manejo dos casais inférteis. A fertilização in vitro clássica foi inicialmente desenvolvida há mais de 35 anos para o tratamento de mulheres com obstrução tubária, no entanto, essa terapêutica permanece ainda inacessível para uma considerável parte dos casais inférteis ao redor do mundo. Isso pode ser explicado pela falta de clínicas especializadas em alguns países e pelo alto custo dos procedimentos. Esforços têm sido empregados para aumentar o número de ciclos de tratamento em reprodução assistida, como, por exemplo, a criação de programas de baixo custo. Ainda nos dias atuais, a infertilidade permanece como um problema de proporções mundiais, acometendo milhões de casais. A estimativa da incidência da infertilidade é incerta, principalmente por causa dos critérios utilizados para sua definição. Este artigo tem como objetivo revisar os aspectos mais importantes, de forma sucinta, referentes a incidência, etiologia e alternativas terapêuticas disponíveis para os casais inférteis.

Palavras-chave: infertilidade, técnicas de reprodução assistida (TRA), fertilização in vitro.

\section{REFERENCES}

1. Shamma FN, DeCherney AH. Infertility: a historical perspective. In: Keye Jr WR, Chang RJ, Rebar RW, Soules MR. Infertility: evaluation and treatment. 1st ed. Philadelphia: W. B. Saunders Company, 1995. 3-7.
2. Gurunath S, Pandian Z, Anderson RA, Bhattacharya S. Definiting infertility - a systematic review of prevalence studies. Hum Reprod. Update 2011; 17(5)575-88.

3. Mascarenhas MN, Cheung H, Mathers CD, Stevens GA. Measuring infertility in populations: constructing a standard definition for use with demographic and reproductive health surveys. Popul Health Metr. 2012a; 10(1):17.

4. Boivin J, Bunting I, Collins JA, Nygren KG. International estimates of infertility prevalence and treatment-seeking: potential need and demand for infertility medical care. Hum Reprod. 2007; 22(6):1506-12.

5. Rutstein SO, Shah IH. Infecundity, Infertility, and Childlessness in Developing Countries. DHS Comparative Report No. 9: Calverton, Maryland, USA: ORC Macro and the World Health Organization, 2004.

6. Mascarenhas MN, Flaxman SR, Boerma T, Vanderpoel S, Stevens GA. National, regional, and global trends in infertility prevalence since 1990: a systematic analysis of 277 health surveys. PLoS Med. 2012b; 9(12):e1001356.

7. Practice Committee of American Society for Reproductive Medicine. Definitions of infertility and recurrent pregnancy loss: a committee opinion. Fertil Steril. 2013; 99(1):63

8. Ombelet W, Cooke I, Dyer S, Serour G, Devroey P. Infertility and the provision of infertility medical services in developing countries. Hum Reprod. Update 2008a; 14(6):605-21.

9. Ombelet W, Devroey P, Gianardi L, te Velde E (eds). Developing countries and infertility. Spec Issue Hum Reprod 2008b; 1-117.

10. Nachtigall RD. International disparities in access to infertility services. Fertil Steril. 2006; 85(4):871-5.

11. Gnoth C, Godehardt D, Godehardt E, Frank-Herrmann P, Freundl G. Time to pregnancy: results of the German prospective study and impact on the management of infertility. Hum Reprod. 2003; 18(9):1959-66.

12. Gnoth C, Godehardt D, Godehardt E, Frank-Herrmann P, Friol K, Tigges J et al. Definition and prevalence of subfertility and infertility. Hum Reprod. 2005; 20(5):1144-7.

13. Collins JA, Van Steirteghem A. Overall prognosis with current treatment of infertility. Hum Reprod. Update 2004; 10(4):309-16.

14. ESHRE Capri Workshop Group. Optimal use of infertility diagnostic tests and treatments. Hum Reprod. 2000; 15(3):723-32.

15. American Society for Reproductive Medicine Practice Committee. Educational Bulletin: Effectiveness and treatment of unexplained infertility. ASRM. 2000; 86(suppl 4):111-4 